\title{
HOW DO STIGMA AND INCOME AFFECT THE RISK OF DEPRESSION AMONG MEN WHO HAVE SEX WITH MEN? A NEW EVIDENCE FROM SURAKARTA, CENTRAL JAVA
}

\author{
Dyah Ayu Agustin',3), Afiono Agung Prasetyo²), Bhisma Murti3) \\ 1)School of Health Sciences Kendedes, Malang, East Java \\ 2)Faculty of Medicine, Universitas Sebelas Maret \\ 3)Masters Program in Public Health, Universitas Sebelas Maret
}

\begin{abstract}
Background: The World Health Organization has projected major depression to be the second greatest contributor to global burden of disease in terms of disability-adjusted life years by the year 2020. Studies have shown that individuals with moderate to severe depression exhibited greater perceived stigma compared to their counterparts. Likewise, there has been increasing concern about the impact of the global economic recession on mental health. Studies have shown that low levels of household income are associated with several lifetime mental disorders and suicide attempts, and a reduction in household income is associated with increased risk for incident mental disorders. This study aimed to examine the relationship between stigma and the risk of depression accounting for the effects of income, education, and family support among men who have sex with men in Surakarta, Central Java.

Subjects and Method: This was a cross sectional study conducted at Dr. Moewardi Hospital, Surakarta, Central Java, on January 2018. A total sample of 70 men who have sex with men was selected for this study. The dependent variable was depression. The independent variables were stigma, income, education, and family support. The data were collected using a pre-tested questionnaire and analyzed by a path analysis.

Results: Depression directly increased with stigma $(b=3.81 ; 95 \% \mathrm{CI}=1.01$ to $6.61 ; \mathrm{p}=0.008)$ but decreased with higher income $(\mathrm{b}=-2.18 ; 95 \% \mathrm{CI}=-4.65$ to $0.29 ; \mathrm{p}=0.084)$. Depression indirectly decreased with higher education and stronger family support.
\end{abstract}

Conclusion: Stigma and income directly affect the risk of depression. Education and family support indirectly affect the risk of depression.

Keywords: depression, stigma, income, education, family support, men who have sex with men

\section{Correspondence:}

Dyah Ayu Agustin. Masters Program in Public Health, Universitas Sebelas Maret, Jl. Ir. Sutami 36 A, Surakarta. Email: ayuagustin20@gmail.com.

Mobile: +6281316337006 . 